\title{
The Emerging Roles of Faculty Staff in Arab Universities of The Requirements of the Fourth Industrial Revolution
}

\author{
Nour EL-din M. Nasar
}

Faculty of Education, Arab Open University

\begin{abstract}
The research aimed to determine the roles developed for faculty members in Arab universities in the requirements of the Fourth Industrial Revolution to achieve this goal the study employed the descriptive analytical approach, to analyze educational heritage and previous relevant studies to characterize the current reality of the roles of faculty members in Arab universities. Defining the concept of the fourth industrial revolution and its implications for university education and use that to define the most important new roles for faculty members in the requirements of the Fourth Industrial Revolution. The research reached to define a number of roles developed in the fields of: Teaching and education, Scientific research, social responsibility and community service, leadership and governance, building a knowledge society nurturing and developing creativity, facing the challenges and dilemmas of the Fourth Industrial Revolution, facing Arab reality crises and facing the challenges of the Corona pandemic.
\end{abstract}

Keywords: Faculty Staff; The Fourth Industrial Revolution; Innovated Roles

Citation: Citation: Nasar, N. The Emerging Roles of Faculty Staff in Arab Universities of The Requirements of the Fourth Industrial Revolution, SVU-Journal of abstract 2020, 2 (1): pp7 (retrieved from the SVU- International Journal Of Educational Sciences,2020, No 5).

Copyright: Publisher South Valley University. This is an open access article distributed under the terms of the creative common attribution license, which permits unrestricted use, distribution and reproduction in any medium provided the original author and source are created. 